\title{
Experimental Study of Environmental Impact on the Efficiency of a House-Hold PV Panel
}

\author{
Yassir Idris Abdalla Osman1,2,3, Jinping Li1,2,3*, Xiaofei Zhen",2,3 \\ ${ }^{1}$ Western China Energy \& Environment Research Center, Lanzhou University of Technology, Lanzhou, China \\ ${ }^{2}$ Gansu Key Laboratory of Complementary Energy System of Biomass and Solar Energy, Lanzhou, China \\ ${ }^{3}$ China Northwestern Collaborative Innovation Center of Key Technology for Northwest Low \\ Carbon Urbanization, Lanzhou, China \\ Email:*yassiromi@hotmail.com
}

How to cite this paper: Osman, Y.I.A., Li, J.P. and Zhen, X.F. (2018) Experimental Study of Environmental Impact on the Efficiency of a House-Hold PV Panel. Smart Grid and Renewable Energy, 9, 113-125. https://doi.org/10.4236/sgre.2018.97008

Received: July 7, 2018

Accepted: July 27, 2018

Published: July 30, 2018

Copyright $\odot 2018$ by authors and Scientific Research Publishing Inc. This work is licensed under the Creative Commons Attribution International License (CC BY 4.0).

http://creativecommons.org/licenses/by/4.0/

\begin{abstract}
House-hold PV panels are widely used; however, their performance is significantly degraded under real operating conditions. Environmental factors such as ambient temperature, wind speed, and solar irradiance has a major impact on the house-hold PV panel efficiency. In this paper an experimental study was conducted during the winter period in a single building in Minqin county, Gansu province, China. The experimental measurements were used to quantify the house-hold PV panel performance and operating characteristics. Based on the experimental results the house-hold PV panel performance is basically affected by the PV surface temperature, therefore, multilevel of energy is detected. Approximately $3 \%$ efficiency variation is detected due to the impact of the environmental factors.
\end{abstract}

\section{Keywords}

House-Hold PV Panel, Environmental Factors, Photovoltaic Efficiency

\section{Introduction}

Among all the available electricity sources, solar photovoltaic (PV) is the most popular for installation [1]. PV technology witnessed a significant reduction in the cost and appreciable progress in increasing the efficiency [2] [3]. Generally, the standard test conditions are considered in most cases to address the PV performance specification, however, there is a considerable variation when the actual conditions are adopted.

A part of the irradiance received by the PV panel is transformed into electricity, and the other is transformed into heat losses which is responsible for reduc- 
ing the PV panel efficiency [4] [5]. Altitude and azimuth play a crucial role in determination of sun position during the day [6]. It is evidence that the maximum reception of solar radiation occurs when the PV panel is perpendicular to the sun radiation [7] [8]. Many publications accounting $0.08 \%$ of loss takes place when the location of the PV panel is diverged from the south particularly in azimuth angle [9]. Basically, the PV panel output power is directly proportion to the solar radiation [10]. Due to the approximate linearity the PV current is increased in accordance with the increment of the solar radiation [11] [12] [13]. Regarding this approximate linearity, the influence of the solar irradiance on the PV output current is hard to enumerate [14] [15].

In order to address the influence of ambient temperature on the PV panel functionality, two parameters exist short circuit current $I_{s c}$ and open circuit volts $V_{o c}$. When the $\mathrm{PV}$ module temperature is increasing, the short circuit witnessed an insignificant increase (ranged between 0.04 and $0.09 \% / \mathrm{K}$ ), in contrast to open circuit voltage, it suffers a considerable degradation (up to $-0.45 \% / \mathrm{K}$ for crystalline silicon) [16] [17]. The efficiency of the PV panel is varied according to the PV type under consideration. In the body of literature, it was reported that when the ambient temperature increased by $1^{\circ} \mathrm{C}$, the efficiency is reduced within the range of $0.35 \%-0.8 \%$ [18] [19] [20] [21]. An experimental work concerns the effects of temperature coefficient on several silicon-based PV types, which reveals a loss of $3 \%-5 \%$ occur as a result of $10^{\circ} \mathrm{C}$ variation [22].

Some publications addressed the influence of ambient temperature on the PV panel performance considering geographical localization. Within the context, the Crystalline PV panel showed a reduction of $0.45 \%$ when the temperature rises $1^{\circ} \mathrm{C}$ in [23] and 0.5 in [24]. For materials such as amorphous silicon, cadmium Telluride and copper-indium-gallium-diselenide which are used in thin film PV panels, the performance degradation falls in the range of $0.21 \%-0.36 \%$ [25] [26] [27] [28]. Generally, the increment in the ambient temperature is correlated with performance degradation, and this fact is revealed in [29] [30]. By considering a water-based cooling technique, the PV surface temperature witness a reduction ranged $5^{\circ} \mathrm{C}$ to $23^{\circ} \mathrm{C}$ which enhance the performance from $0 \%$ to $22 \%$ [31].

Many researchers have proposed different approaches regarding the influence of wind on the PV module temperature. Wind has the ability of cooling the PV module within the range of $15^{\circ} \mathrm{C}-20^{\circ} \mathrm{C}$ when the wind speed is $10 \mathrm{~m} / \mathrm{s}$ under $1000 \mathrm{~W} / \mathrm{m}^{2}$ of solar irradiance [32]. A considerable variation on the PV panel operation characteristic is detected due to the high dynamic nature of the Wind [29] [33]. In highly dynamic wind regions, the PV panel performance reaches up to $18 \%$, according to the experimental results in [34]. However, the influence of the wind speed on the PV panel performance is quietly trivial in contrast to the ambient temperature and solar irradiance. A method known as in-situ is considered in order to examine the experimental data and for validation purpose. One drawback associated with this method is that, the experimental data need to be 
substituted by numerical weather prediction [35] [36].

Generally, the house-hold PV panel is affected by numerous environmental factors such as seasonal variation, humidity, rainfall, positioning, etc. However, the influences of these factors are not considered in this investigation.

Regarding the unique weather conditions of Minqin County, the house-hold PV panel performance is expected to vary in many aspects. Accordingly, the main objective of this work is to quantify the performance of the house-hold PV panel and reveal the operating characteristics as well based on the experimental results.

A house-hold PV panel system was built and tested as well. The environmental factors are measured and recorded through the data acquisition equipment. The experimental results are extensively analyzed and discussed.

\section{Photovoltaic Surface Temperature Theory}

The relationship regarding the ambient temperature $\left(T_{a}\right)$ and the photovoltaic surface temperature $\left(T_{p v}\right)$ is nearly linear. Basically, the variation of $\left(T_{p v}\right)$ and $\left(T_{a}\right)$ is a function of solar irradiance, and this result is associated with the effect of wind speed. The parameter $\left(T_{p v}\right)$ is a function of $\left(T_{a}\right)$ insignificantly influenced by solar irradiance $(G)$ and wind speed $(v)$. By taking into account the standard values for beta coefficients $0.74,0.33$, and -0.11 respectively, the corresponding linear correlation is obtained [37].

$$
\begin{aligned}
T_{p v}= & 2.08( \pm 0.13)+1.038( \pm 0.004) \cdot T_{a}+0.0182( \pm 0.0001) \cdot G \\
& -1.13( \pm 0.02) \cdot v\left(R^{2}=0.96\right)
\end{aligned}
$$

The most common expression addressed the $P V$ module temperature is given in Equation (2)

$$
T_{p v}=T_{a}+\frac{1}{G_{(N O C T)}} \cdot\left(T_{N O C T}-T_{a, N O C T}\right)
$$

where $T_{N O C T}$ is the temperature at nominal operating cell temperature ( $G_{(N O C T)}$ $\left.=800 \mathrm{~W} / \mathrm{m}^{2}, T_{a}=20^{\circ} \mathrm{C}, V=1 \mathrm{~m} / \mathrm{s}\right), T_{N O C T}$ is varying according to the PV technology a typical value for $T_{N O C T}$ is $45^{\circ} \mathrm{C}$. According to the literature, the typical $\mathrm{PV}$ operating temperature is at $45^{\circ} \mathrm{C}$, the best at $33^{\circ} \mathrm{C}$ and the worst at $58^{\circ} \mathrm{C}$ [38]. This expression does not consider the wind cooling influence.

A compact $\mathrm{PV}$ temperature expression is given by:

$$
T_{p v}=T_{a}+0.035 \cdot G
$$

In order to consider wind speed factor, the following expression can be used:

$$
T_{p v}=T_{a}+\frac{0.032}{8.91+2 \cdot v} \cdot G
$$

\section{PV Efficiency Theory}

The efficiency of the PV panel is positively influenced by wind speed. However, this influence is not vital. Within the body of literature, it is reported that, the 
wind speed influence varies between 1.3 and $1.65 \mathrm{~m} / \mathrm{s}$ [28] [29] [30] [31] [32]. However, regarding the high dynamic nature of wind factor, it is quite difficult to be quantified. The factor that has a vital influence on the PV efficiency is the $T_{p v}$. By associating these values $0.85,-0.39$, and 0.32 respectively, for standard beta coefficient, the following linear correlation is obtained to address the actual $\mathrm{PV}$ efficiency $(\eta \%)$

$$
\begin{aligned}
\eta= & 6.2 \cdot( \pm 0.2)-0.0312 \cdot( \pm 0.0004) \cdot T_{p v}-0.176( \pm 0.007) \cdot A M \\
& +4.2( \pm 0.2) \cdot \tau \alpha(\theta)\left(R^{2}=0.53\right)
\end{aligned}
$$

where $\alpha$ and $\tau$ are absorptance and transmittance respectively. AM is the air mass (1.6) [39], and $\theta$ is the solar zenith angle.

Another expression that associates the actual operating condition and the standard test condition (STC) is given by:

$$
\begin{aligned}
\eta= & -1.7( \pm 0.2)+0.631( \pm 0.008) \cdot \eta_{k}-0.176( \pm 0.007) \cdot A M \\
& +4.2( \pm 0.2) \cdot \tau \alpha(\theta)\left(R^{2}=0.53\right)
\end{aligned}
$$

where $\eta_{k}$ is efficiency under specific STC conditions.

Based on Equation (5) and Equation (6) the actual efficiency is addressed as:

$$
\begin{aligned}
\eta= & 7.8( \pm 0.2)-3.74( \pm 0.07) \cdot 10^{-2} \cdot T_{a, x}-3.2( \pm 0.2) \cdot 10^{-4} \cdot G+0.8( \pm 0.3) \cdot 10^{-2} \cdot v \\
& -0.197( \pm 0.008) \cdot A M+2.6( \pm 0.2) \cdot \tau \alpha(\theta)\left(R^{2}=0.51\right)
\end{aligned}
$$

The amount of average deviation when Equation (7) is considered to calculate the photovoltaic efficiency is about $2 \%$ of the actual measured efficiency. It is evidence that Equation (7) can be used to predict the photovoltaic efficiency regardless region variation, environmental factors and season variation [37].

\section{Experimental Setup}

This experiment is conducted in a single building in Minqin county. The lowest average solar radiation on the tilted surface of the local altitude is $13 \mathrm{MJ} / \mathrm{m}^{2}$ while the peak solar irradiance is $15 \mathrm{MJ} / \mathrm{m}^{2}$.

The PV panels are fabricated by Xinsheng PV Technology Co. Ltd. A total of 10 monocrystalline silicon PV is utilized. The PV specifications are listed in Table 1 . The overall DC of the batteries group is $24 \mathrm{~V}$, the inverter efficiency is $80 \%$, and the battery depth is $60 \%$.

The list of the experimental instruments is presented in Table 2 followed by the schematic of the experiment setup Figure 1.

\section{Experimental Analysis}

For this experiment the following factors are considered and quantified, the wind speed $\left(v, \mathrm{~m} / \mathrm{s}^{2}\right)$, solar irradiance $\left(\mathrm{G}, \mathrm{W} / \mathrm{m}^{2}\right)$, ambient temperature $\left(T_{a},{ }^{\circ} \mathrm{C}\right)$, photovoltaic surface temperature $\left(T_{p r}{ }^{\circ} \mathrm{C}\right)$. This experiment is conducted over one week started at 9 Feb. 2015 and ended on 15 Feb. 2015. The process of collecting data extended from 0800 o'clock to 1900 o'clock, each day 8286 
Table 1. PV panel specification.

\begin{tabular}{cc}
\hline Peak Power (Pmax) & $100 \mathrm{w}$ \\
Voltage at Pmax & $18 \mathrm{~V}$ \\
Current at Pmax & $5.55 \mathrm{~A}$ \\
Current at Pmax & $21.6 \mathrm{~V}$ \\
Open circuit voltage & $21.6 \mathrm{~V}$ \\
Short circuit current & $5.95 \mathrm{~A}$ \\
Size & $1200^{\star 5} 540^{\star} 30 \mathrm{~mm}$ \\
Weight & $9.0 \mathrm{KGS}$ \\
\hline
\end{tabular}

Table 2. The experimental instruments.

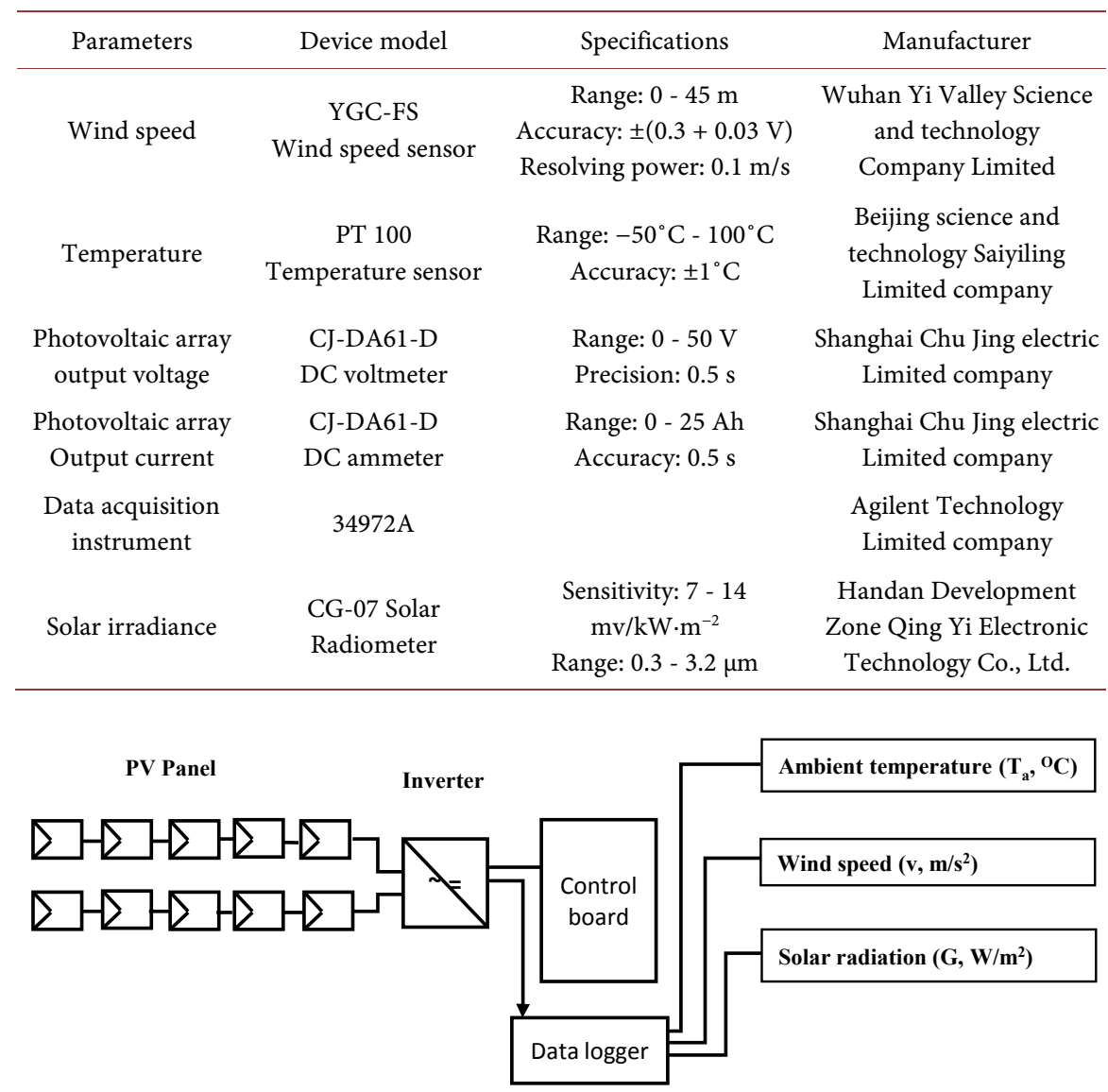

Figure 1. Schematic diagram of the experiment setup.

measurements are recorded. Figure 2(a) presents the temperature for the entire week, and boxplot is adopted to present the measurements. Measurement ranged $1^{\text {st }}$ to $3^{\text {rd }}$ quartile is included within the box and the difference is known as the interquartile range (IQR). The minimum and the maximum are presented by whiskers below and above the rectangular respectively. Measurements that are three times or greater than the $3^{\text {rd }}$ quartile or three times the inter quartile range or lower than the $1^{\text {st }}$ quartile are designated outlier and plotted as red plus signs. 


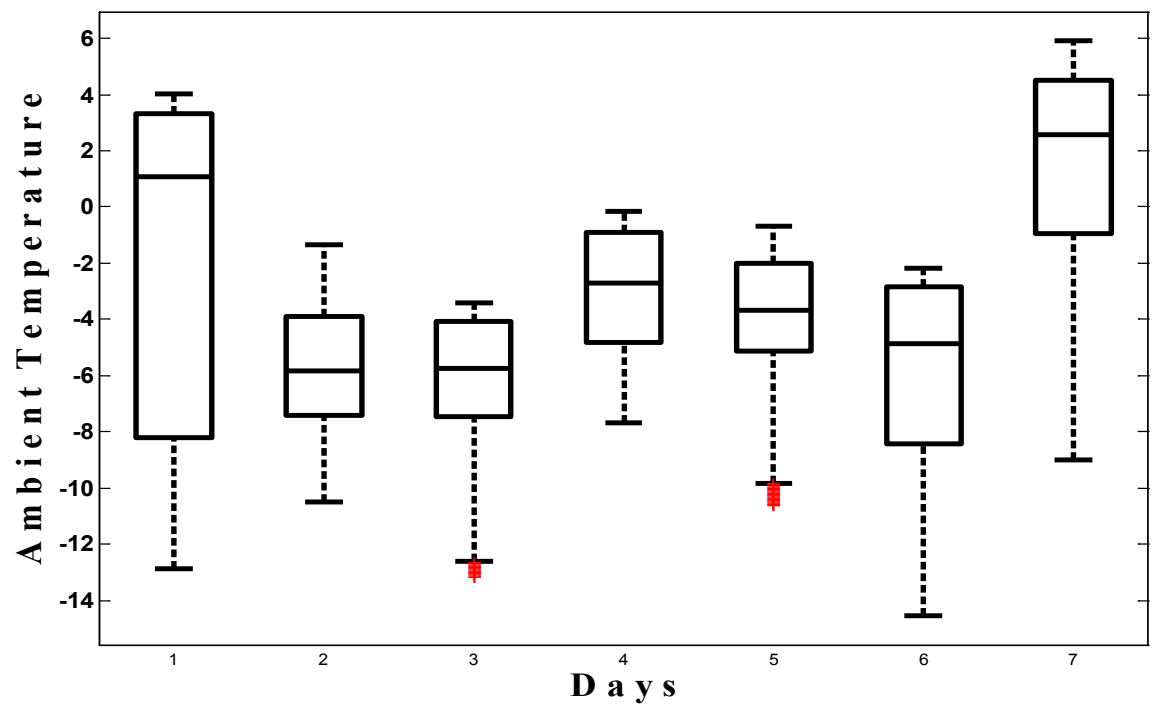

(a)

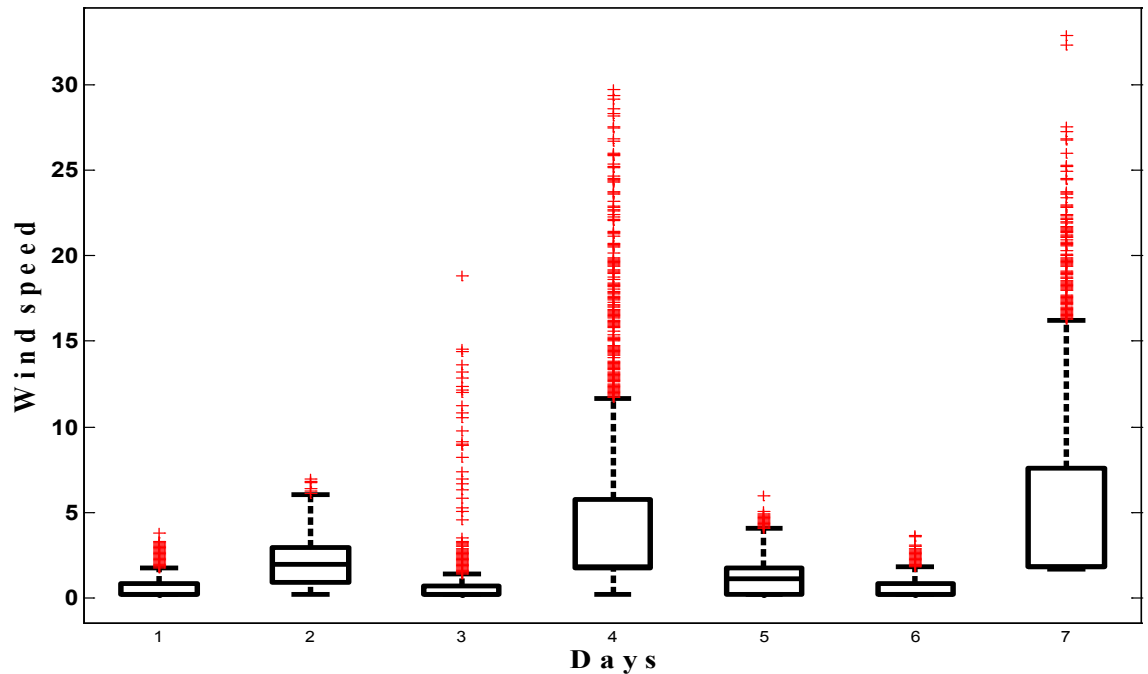

(b)

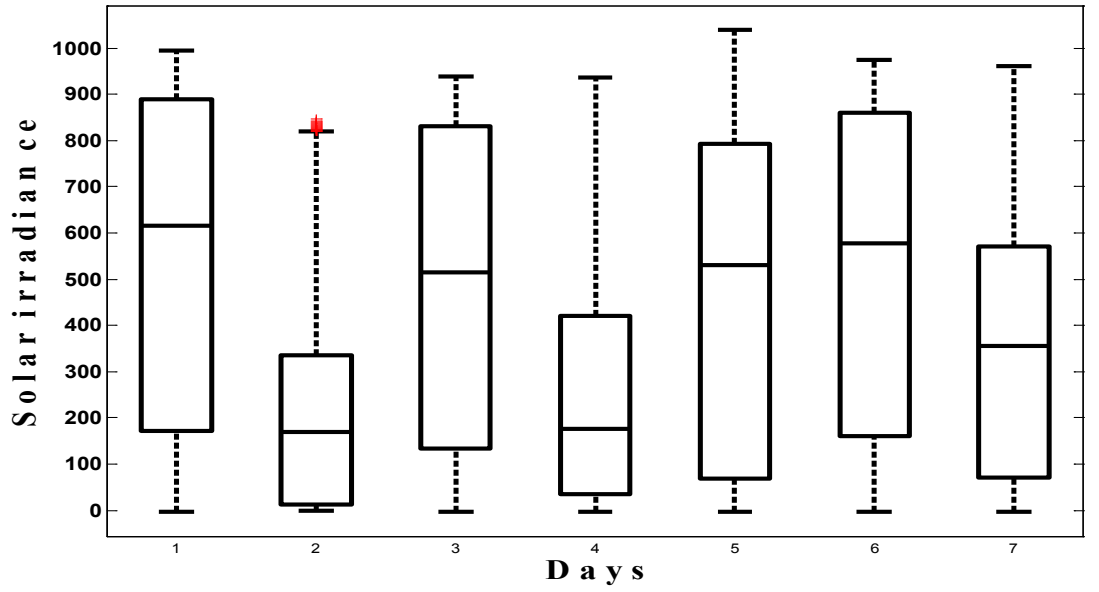

(c)

Figure 2. Statistical plots of the experimental measurements of (9 Feb. 2015-15 Feb. 2015). (a) Ambient temperature; (b) Wind speed; (c) Solar irradiance. 
Figure 2(a) reveals that the minimum ambient temperature is $-14.6^{\circ} \mathrm{C}$ detected on the $6^{\text {th }}$ day, the maximum temperature is $5.9^{\circ} \mathrm{C}$ detected in the $7^{\text {th }}$, while the maximum mean is $1.31^{\circ} \mathrm{C}$ detected in the $7^{\text {th }}$. The outliers only detected in the $3^{\text {th }}$ and $5^{\text {th }}$ days where the temperature falls below $-13.2^{\circ} \mathrm{C}$ and $-10.7^{\circ} \mathrm{C}$ respectively. According to the measurements the temperature is less than $16^{\circ} \mathrm{C}$ a day. Figure 2(b) shows the record of the wind speed data per day for the same week. A significant variation is shown by the wind speed and described by several outliers. The minimum wind speed is $0.18 \mathrm{~m} / \mathrm{s}$ detected on the $3^{\text {th }}$ day, the maximum wind speed is $32.97 \mathrm{~m} / \mathrm{s}$ is detected on the $7^{\text {th }}$ day, and the maximum mean is $4.99 \mathrm{~m} / \mathrm{s}$ detected on the $7^{\text {th }}$ day. Generally, the wind variation is lower than 33 $\mathrm{m} / \mathrm{s}$. The solar irradiance measurements are shown in Figure 2(c) for the same period. The outliers are only detected on the $2^{\text {nd }}$ day when the solar radiation is exceeding $800 \mathrm{~W} / \mathrm{m}^{2}$. The minimum solar irradiance is $-3.8 \mathrm{~W} / \mathrm{m}^{2}$ witnessed on the $1^{\text {st }}$ day, the maximum solar irradiance is 1040 measured on the $5^{\text {th }}$ day, and the maximum mean is $536.3 \mathrm{~W} / \mathrm{m}^{2}$ recorded on the $1^{\text {st }}$ day. The variation of solar irradiance during the experiment is more than $800 \mathrm{~W} / \mathrm{m}^{2}$ per day.

In Figure 3 the $\left(T_{p v}\right)$ and $\left(T_{a}\right)$ are depicted as a function of the day hours for all measurements of the week. These figures reveal the dependence of PV surface temperature on the solar irradiance.

What is interesting about the data in Table 3 is that at 0800 and 1900 0'clock in some days the $\left(T_{p v}\right)$ measurements are lower than $\left(T_{a}\right)$. This is mainly due to the influence of wind.

Based on the experimental results, as shown in Figure 4 the minimum efficiency is $11.52 \%$ achieved during the $5^{\text {th }}$ day where the wind speed is ranged between $1.19 \mathrm{~m} / \mathrm{s}$ and $5.97 \mathrm{~m} / \mathrm{s}$; the minimum and maximum ambient temperature is $-10.7^{\circ} \mathrm{C}$ and $-0.67^{\circ} \mathrm{C}$ respectively; the mean of ambient temperature is $-4.2^{\circ} \mathrm{C}$; the solar irradiance is ranged $(-2.80-408.4) \mathrm{W} / \mathrm{m}^{2}$.

The maximum efficiency being $14.75 \%$ is detected during the $1^{\text {st }}$ day where the wind speed is ranged between $(0.2-3.75) \mathrm{m} / \mathrm{s}$; the ambient temperature is ranged between $(-12.9-4.03)$; the solar irradiance is ranged between $(-3.84$ 994) $\mathrm{W} / \mathrm{m}^{2}$. Generally, when the solar irradiance witnesses a significant increase, the instantaneous value of the efficiency is reduced, particularly, when the solar

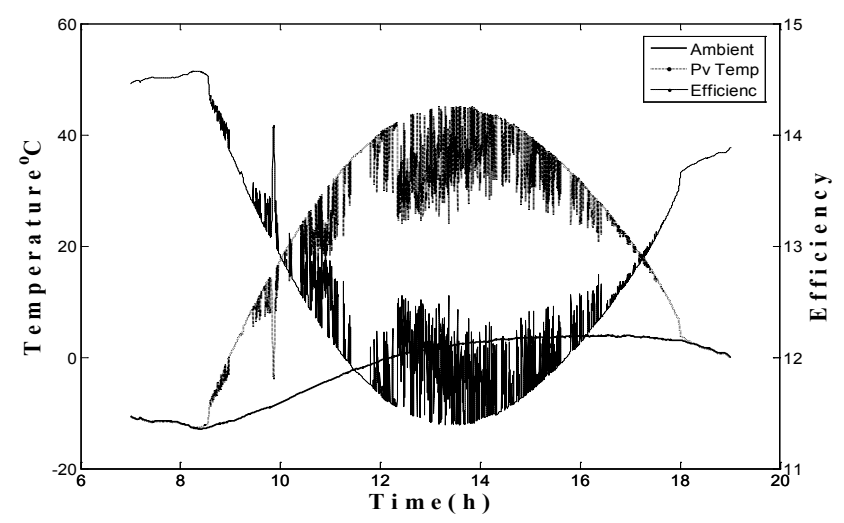

(a) 


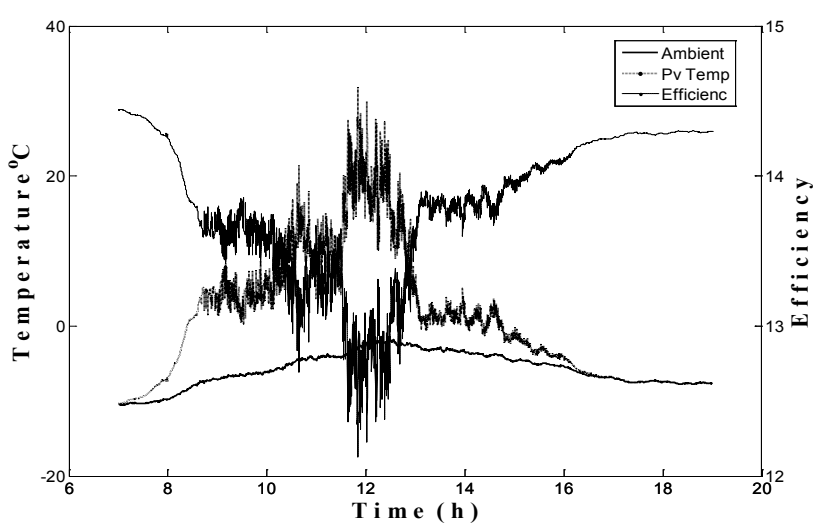

(b)

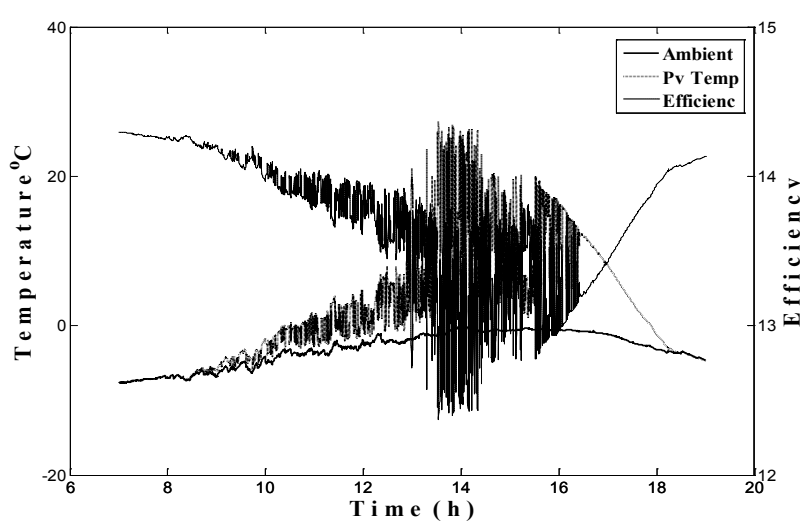

(d)

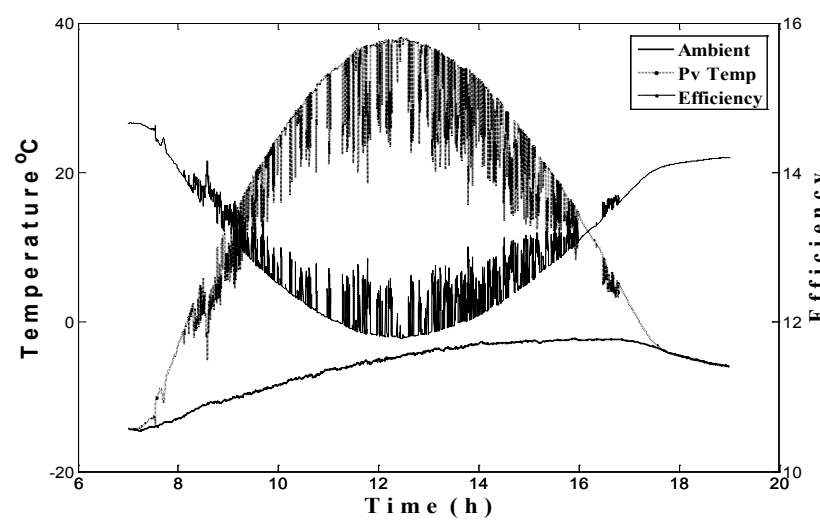

(f)

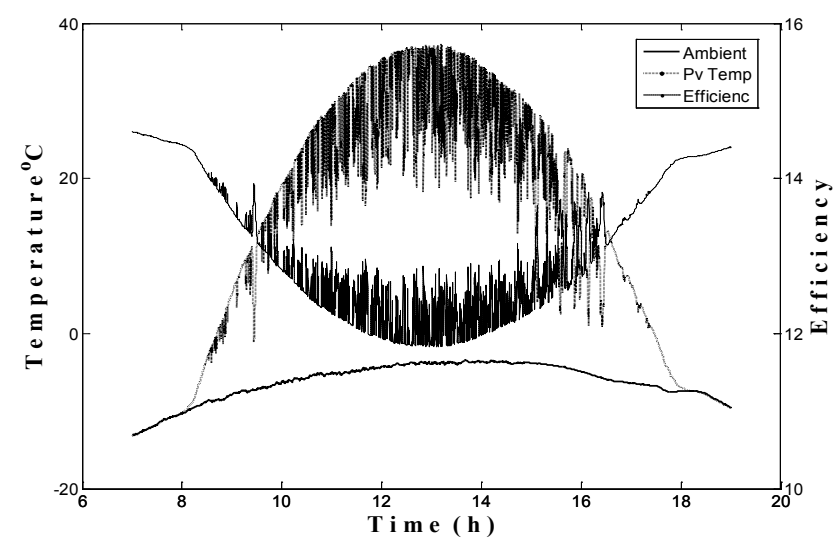

(c)

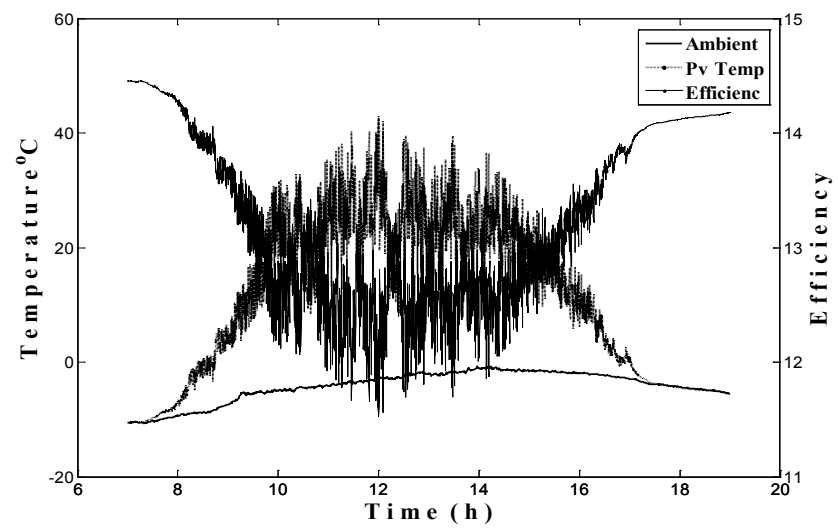

(e)

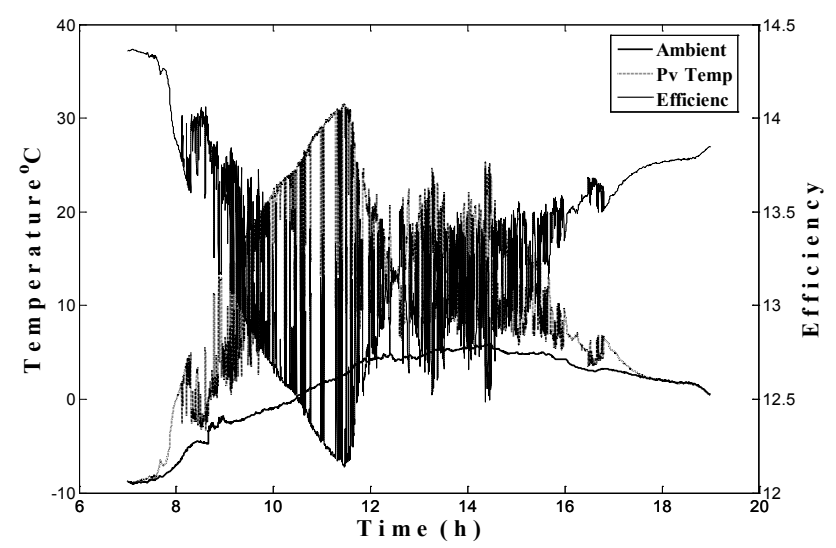

(g)

Figure 3. Ambient temperature, PV surface temperature, and the efficiency as a function of day hours for the entire week. (a) $1^{\text {st }}$ day; (b) $2^{\text {nd }}$ day; (c) $3^{\text {rd }}$ day; (d) $4^{\text {th }}$ day; (e) $5^{\text {th }}$ day; (f) $6^{\text {th }}$ day.

irradiance exceeds $800 \mathrm{~W} / \mathrm{m}^{2}$, this due to the considerable increase of the photovoltaic surface temperature as shown in Figure 5.

\section{Conclusions}

In this paper the influences of the environmental factors such as solar radiation, wind speed, and ambient temperature on the house-hold PV panel efficiency are 
Table 3. Statistical values of ambient temperature and PV surface temperature.

\begin{tabular}{ccccccc}
\hline \multicolumn{3}{c}{ Ambient temperature } & \multicolumn{3}{c}{ PV temperature } & \multirow{2}{*}{ Days } \\
\cline { 1 - 5 } $\min$ & $\max$ & $\operatorname{mean}$ & $\min$ & $\max$ & $\operatorname{mean}$ & \\
\hline-12.9 & 4.03 & -1.93 & -12.7 & 45.16 & 19.11 & $1^{\text {th }}$ \\
-10.5 & -1.36 & -5.77 & -10.4 & 31.80 & 0.99 & $2^{\text {th }}$ \\
-13.2 & -3.41 & -6.22 & -13.2 & 37.28 & 12.95 & $3^{\text {th }}$ \\
-7.68 & -0.13 & -3.11 & -7.68 & 27.38 & 2.57 & $4^{\text {th }}$ \\
-10.7 & -0.67 & -4.21 & -10.6 & 42.73 & 11.19 & $5^{\text {th }}$ \\
-14.6 & -2.18 & -6.01 & -14.4 & 38.13 & 14.62 & $6^{\text {th }}$ \\
-9.02 & 5.93 & 1.31 & -8.97 & 31.58 & 9.62 & $7^{\text {th }}$ \\
\hline
\end{tabular}
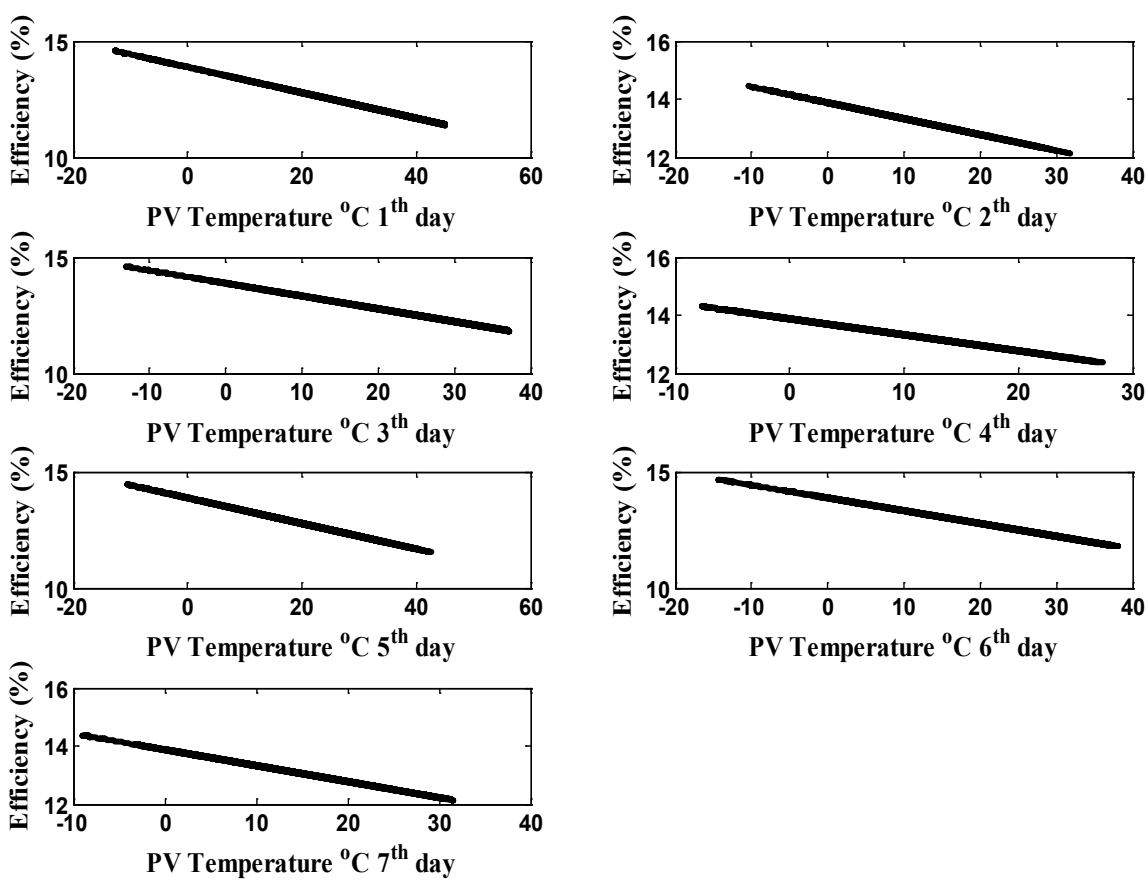

Figure 4. The plots of the efficiency as a function of PV surface temperature of (9 Feb. 2015-15 Feb. 2015).

investigated and quantified. Based on the experimental results, the house-hold $\mathrm{PV}$ panel performance is considerably varied. This deviation is ranged between $11.39 \%-14.75 \%$.

The house-hold PV panel performance is basically affected by the PV surface temperature, therefore, multilevel of energy is detected. Approximately, $3 \%$ efficiency variation is detected.

This investigation is exclusively considered solar radiation, wind speed, and ambient temperature as an environmental factor, and future work should associate other factors such as humidity, rainfall, seasonal variation.

Investigating and analyzing the influence of the environmental factors on the 

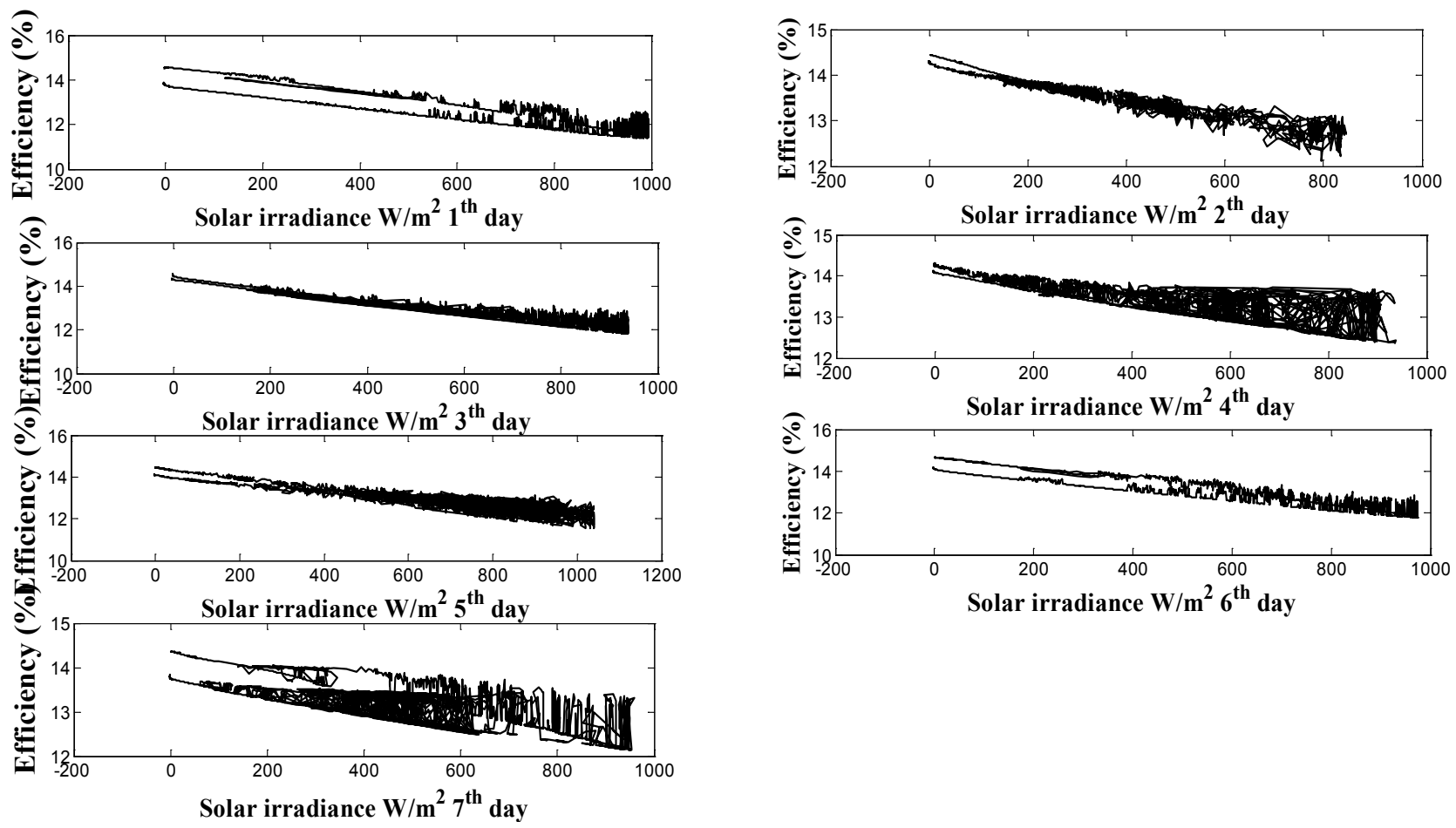

Figure 5. The plots of the efficiency as a function of solar radiation of (9 Feb. 2015-15 Feb. 2015).

house-hold PV panel facilitate the process of assessment and prediction of performance and the harvested power and thus accurately size the PV plants.

\section{Conflicts of Interest}

The authors declare no conflicts of interest regarding the publication of this paper.

\section{References}

[1] Honrubia-Escribano, A., et al. (2018) Influence of Solar Technology in the Economic Performance of PV Power Plants in Europe: A Comprehensive Analysis. Renewable and Sustainable Energy Reviews, 82, 488-501.

https://doi.org/10.1016/j.rser.2017.09.061

[2] Obeidat, F. (2018) A Comprehensive Review of Future Photovoltaic Systems. Solar Energy, 163, 545-551. https://doi.org/10.1016/j.solener.2018.01.050

[3] Bai, A., et al. (2016) Technical and Economic Effects of Cooling of Monocrystalline Photovoltaic Modules under Hungarian Conditions. Renewable and Sustainable Energy Reviews, 60, 1086-1099. https://doi.org/10.1016/j.rser.2016.02.003

[4] Ndiaye, A., et al. (2014) Degradation Evaluation of Crystalline-Silicon Photovoltaic Modules after a Few Operation Years in a Tropical Environment. Solar Energy, 103, 70-77. https://doi.org/10.1016/j.solener.2014.02.006

[5] Kahoul, N., Houabes, M. and Sadok, M. (2014) Assessing the Early Degradation of Photovoltaic Modules Performance in the Saharan Region. Energy Conversion and Management, 82, 320-326. https://doi.org/10.1016/j.enconman.2014.03.034

[6] Sen, R. and Bhattacharyya, S.C. (2014) Off-Grid Electricity Generation with Re- 
newable Energy Technologies in India: An Application of HOMER. Renewable Energy, 62, 388-398. https://doi.org/10.1016/j.renene.2013.07.028

[7] Sieminski, A. (2014) International Energy Outlook. Energy Information Administration (EIA), 18.

[8] Outlook, A.E. (2010) International Energy Outlook. 92010, Energy Information Administration, Department of Energy, 1-15.

[9] Touati, F., et al. (2016) Investigation of Solar PV Performance under Doha Weather Using a Customized Measurement and Monitoring System. Renewable Energy, 89, 564-577. https://doi.org/10.1016/j.renene.2015.12.046

[10] Bendib, B., Belmili, H. and Krim, F. (2015) A Survey of the Most Used MPPT Methods: Conventional and Advanced Algorithms Applied for Photovoltaic Systems. Renewable and Sustainable Energy Reviews, 45, 637-648. https://doi.org/10.1016/j.rser.2015.02.009

[11] Skoplaki, E. and Palyvos, J. (2009) Operating Temperature of Photovoltaic Modules: A Survey of Pertinent Correlations. Renewable Energy, 34, 23-29. https://doi.org/10.1016/j.renene.2008.04.009

[12] Alami, A.H. (2014) Effects of Evaporative Cooling on Efficiency of Photovoltaic Modules. Energy Conversion and Management, 77, 668-679. https://doi.org/10.1016/j.enconman.2013.10.019

[13] Nižetić, S., et al. (2016) Water Spray Cooling Technique Applied on a Photovoltaic Panel: The Performance Response. Energy Conversion and Management, 108, 287-296. https://doi.org/10.1016/j.enconman.2015.10.079

[14] Polo, J., Fernandez-Neira, W. and Alonso-García, M. (2017) On the Use of Reference Modules as Irradiance Sensor for Monitoring and Modelling Rooftop PV Systems. Renewable Energy, 106, 186-191. https://doi.org/10.1016/j.renene.2017.01.026

[15] Yang, D. (2017) On Adding and Removing Sensors in a Solar Irradiance Monitoring Network for Areal Forecasting and PV System Performance Evaluation. Solar Energy, 155, 1417-1430. https://doi.org/10.1016/j.solener.2017.07.061

[16] Abdolzadeh, M. and Ameri, M. (2009) Improving the Effectiveness of a Photovoltaic Water Pumping System by Spraying Water over the Front of Photovoltaic Cells. Renewable Energy, 34, 91-96. https://doi.org/10.1016/j.renene.2008.03.024

[17] Habiballahi, M., Ameri, M. and Mansouri, S. (2015) Efficiency Improvement of Photovoltaic Water Pumping Systems by Means of Water Flow Beneath Photovoltaic Cells Surface. Journal of Solar Energy Engineering, 137, Article ID: 044501. https://doi.org/10.1115/1.4029932

[18] Aelenei, L., et al. (2014) Thermal Performance of a Hybrid BIPV-PCM: Modeling, Design and Experimental Investigation. Energy Procedia, 48, 474-483. https://doi.org/10.1016/j.egypro.2014.02.056

[19] Ibrahim, H. and Anani, N. (2017) Variations of PV Module Parameters with Irradiance and Temperature. Energy Procedia, 134, 276-285.

https://doi.org/10.1016/j.egypro.2017.09.617

[20] Elbreki, A., et al. (2017) Towards Adopting Passive Heat Dissipation Approaches for Temperature Regulation of PV Module as a Sustainable Solution. Renewable and Sustainable Energy Reviews, 69, 961-1017. https://doi.org/10.1016/j.rser.2016.09.054

[21] Bouraiou, A., et al. (2018) Experimental Investigation of Observed Defects in Crystalline Silicon PV Modules under Outdoor Hot Dry Climatic Conditions in Algeria. Solar Energy, 159, 475-487. https://doi.org/10.1016/j.solener.2017.11.018 
[22] Masuko, K., et al. (2014) Achievement of More Than 25\% Conversion Efficiency with Crystalline Silicon Heterojunction Solar Cell. IEEE Journal of Photovoltaics, 4 , 1433-1435. https://doi.org/10.1109/JPHOTOV.2014.2352151

[23] Kazem, H.A. and Chaichan, M.T. (2016) Experimental Analysis of the Effect of Dust's Physical Properties on Photovoltaic Modules in Northern Oman. Solar Energy, 139, 68-80. https://doi.org/10.1016/j.solener.2016.09.019

[24] Kankiewicz, A., Sengupta, M. and Moon, D. (2010) Observed Impacts of Transient Clouds on Utility-Scale PV Fields. Proceedings of ASES National Solar Conference, Phoenix, Arizona, USA, 17-22 May 2010.

[25] Curtright, A.E. and Apt, J. (2008) The Character of Power Output from Utility-Scale Photovoltaic Systems. Progress in Photovoltaics: Research and Applications, 16, 241-247. https://doi.org/10.1002/pip.786

[26] Li, N., Liu, C. and Zha, D. (2016) Performance Evaluation of Chinese Photovoltaic Companies with the Input-Oriented Dynamic SBM Model. Renewable Energy, 89, 489-497. https://doi.org/10.1016/j.renene.2015.12.028

[27] Azadeh, A., Ghaderi, S. and Maghsoudi, A. (2008) Location Optimization of Solar Plants by an Integrated Hierarchical DEA PCA Approach. Energy Policy, 36, 3993-4004. https://doi.org/10.1016/j.enpol.2008.05.034

[28] Sueyoshi, T. and Goto, M. (2014) Photovoltaic Power Stations in Germany and the United States: A Comparative Study by Data Envelopment Analysis. Energy Economics, 42, 271-288. https://doi.org/10.1016/j.eneco.2014.01.004

[29] García-Domingo, B., et al. (2014) Modelling the Influence of Atmospheric Conditions on the Outdoor Real Performance of a CPV (Concentrated Photovoltaic) Module. Energy, 70, 239-250. https://doi.org/10.1016/j.energy.2014.03.119

[30] Nishioka, K., et al. (2003) Field-Test Analysis of PV System Output Characteristics Focusing on Module Temperature. Solar Energy Materials and Solar Cells, 75, 665-671. https://doi.org/10.1016/S0927-0248(02)00148-4

[31] Al-Shamani, A.N., et al. (2014) Nanofluids for Improved Efficiency in Cooling Solar Collectors-A Review. Renewable and Sustainable Energy Reviews, 38, 348-367. https://doi.org/10.1016/j.rser.2014.05.041

[32] McColl, S.J., Rodgers, P. and Eveloy, V. (2015) Thermal Management of Solar Photovoltaics Modules for Enhanced Power Generation. Renewable Energy, 82, 14-20. https://doi.org/10.1016/j.renene.2014.09.015

[33] Gökmen, N., et al. (2016) Investigation of Wind Speed Cooling Effect on PV Panels in Windy Locations. Renewable Energy, 90, 283-290.

https://doi.org/10.1016/j.renene.2016.01.017

[34] Obara, S.Y., et al. (2014) Output Prediction of Large-Scale Photovoltaics by Wind-Condition Analysis Using 3D Topographic Maps. Solar Energy, 105, 157-169. https://doi.org/10.1016/j.solener.2014.03.007

[35] Schwingshackl, C., et al. (2013) Wind Effect on PV Module Temperature: Analysis of Different Techniques for an Accurate Estimation. Energy Procedia, 40, 77-86. https://doi.org/10.1016/j.egypro.2013.08.010

[36] Koehl, M., et al. (2011) Modeling of the Nominal Operating Cell Temperature Based on Outdoor Weathering. Solar Energy Materials and Solar Cells, 95, 1638-1646. https://doi.org/10.1016/j.solmat.2011.01.020

[37] Gaglia, A.G., et al. (2017) Energy Efficiency of PV Panels under Real Outdoor Conditions-An Experimental Assessment in Athens, Greece. Renewable Energy, 101, 236-243. https://doi.org/10.1016/j.renene.2016.08.051 
[38] Migan, G.-A. (2013) Study the Operating Temperature of a PV Module. Project Report.

[39] Commission, I.E. (2005) Crystalline Silicon Terrestrial Photovoltaic (PV) Modules-Design Qualification and Type Approval. International Standard IEC, 61215-04. 